\title{
Second International Conference on User Education
}

One hundred thirty librarians from different types of libraries in fourteen different countries convened from July $7-10,1981$, at Keble College, Oxford University, for the Second International Conference on User Education. The six conference organizers Nancy Aberle (Brighton Polytechnic), John Burchell (British Library), Daphne Clark (Hartfield Polytechnic), Ann Edmunds (Oxford Polytechnic), Peter Fox (Trinity College, Dublin), Ian Malley (Loughborough University), and Catherine Tranmer (Oxford Polytechnic) are to be commended for planning a most ambitious and successful program for the participants. Conference attendees were exposed to eighteen papers on library user instruction in school, public, special, and academic libraries by experienced speakers from England, Scotland, Ireland, the United States, Australia, and Turkey.

Constance Mulligan from Northern Kentucky University started the conference program with a stimulating paper on bibliographic jargon as a barrier to user education.

Dai Hounsell from the University of Lancaster discussed librarians' problems of isolation and lack of resources in teaching and learning information skills. This was followed by a presentation from Jim Herring of Aberdeen about school librarians' endeavor to integrate library skills into the curriculum and the politics of doing this. Terrence Brake from the Curriculum Research Unit in London continued this theme by addressing the importance of teaching library skills in secondary schools as part of the total skills program. The design and development of a preschool to adult library instruction curriculum in a Michigan school was outlined by Edward Marman who ended on the sad note that current budget cuts had eliminated this program.

Bob Pearce, library science professor from Dublin, discussed the problem of foreign students' lack of library skills and how to deal with it.

Social services staff needs for user education was addressed by David Streatfield from the National Foundation for Educational Research in England and Wales.

Hannelore Rader from the University of Wisconsin-Parkside delivered a paper on the importance of integrating user instruction into the academic curriculum. David Jones from Sheffield University added to this theme with a discussion on team teaching in user education.
Two papers on evaluation of user instruction were given by U.S. librarians. John Lubans, Jr., from the University of Houston provided some methodological observations and suggestions about evaluation designs. Mary Reichel from Georgia State University presented a paper written jointly with Rao Aluri on using cognitive learning theory in user instruction and evaluating students learning in that way.

John James (Sheffield) and David Fulljames (Wolverhampton Polytechnic) described a fouryear longitudinal study of the interactions of science students with polytechnic libraries.

A survey of user education in Australia was presented by Patrick Condon, while Gulcin Cribb from Turkey discussed user education in a developing country.

The final paper was delivered by Deborah Masters from SUNY-Albany on educating library users for computerized literature searching and computerized library services in U.S. academic libraries.

Conference attendees were also able to participate in several group discussions and view a number of media and print materials on library instruction. A variety of social events, visits to Blackwells, other antiquarian bookshops, and various famous libraries like the Bodleian in combination with living four days within the famous halls of Oxford University kept all conference participants extremely busy and provided them with a very rich cultural and educational experience.

The proceedings of this conference will be published by the British Library in the near future.-Hannelore B. Rader.

Editor's Note: Hannelore Rader is Director of the Library Learning Center, University of Wisconsin-Parkside, Kenosha, Wisconsin.

\section{Information Needed}

Information is sought on the location of manuscript letters and other materials relating to the life of the famous American Quaker and grammarian Lindley Murray (1745-1826). Please send any information to Prof. D. A . Reibel, Englisches Seminar, Wilhelmstrasse 50, D-7400 Tübingen 1, West Germany. 


\section{ACADEMIC/RESEARCH LIBRARIAN OF THE YEAR AWARD}

The Association of College and Research Libraries invites nominations for the Academic or Research Librarian of the Year Award, presented jointly by ACRL and the Baker \& Taylor Company. Anyone wishing to submit nominations should request a nomination form from the ACRL office, 50 E. Huron St., Chicago, IL 60611 .

Recipients of the award since its inception in 1978 have been: Keyes D. Metcalf and Robert B. Downs (1978); Henriette D. Avram and Frederick G. Kilgour (1979); Evan I. Farber (1980); and Beverly P. Lynch (1981).

The Awards Committee selects persons to receive the award in accordance with the following guidelines:

PURPose: To recognize an individual member of the library profession who has made an outstanding national or international contribution to academic or research librarianship and library development

CrITERIA: Individuals nominated should have demonstrated achievements in such areas as:

1. Service to the organized profession through ACRL and related organizations.

2. Significant and influential research on academic or research library service.

3. Publication of a body of scholarly and/or theoretical writing contributing to academic or research library development.

4. Planning and implementing a library program of such exemplary quality that it has served as a model for others.

5. Nominee does not have to meet all of the above criteria

Rules: The award shall be made each year at a time and place to be determined by the ACRL Board of Directors. Announcement of the award shall be made by the ACRL president at a time and place to be determined by the ACRL Board of Directors. If, in the opinion of the Award Committee, no worthy candidate is nominated in a given year, the award will not be presented that year.

Nominations: Nominations for the award must be returned to the chair of the Academic/ Research Librarian of the Year Award Committee and must be postmarked no later than January 1, 1982. Nominations must be submitted in quintuplicate. Please do not solicit supporting letters seconding your nomination. Such letters will not be considered in the Award Committee's decision.

Nature of THE AWARD: The Academic/ Research Librarian of the Year Award shall consist of $\$ 2,000$ and an appropriate citation.

The Awards Committee for 1982 consists of the following persons: Pearce S. Grove (chair), Research Division, National Endowment for the
Humanities, 806 15th Street NW, Washington, DC 20506; Sherrie S. Bergman, College Librarian, Wheaton College, Norton, MA 02766; Marcia S. Myers, Associate Director of Libraries for Administrative Services, Maine Library, University of Tennessee, Knoxville, TN 37917; Patricia G. Oyler, Associate Professor, Simmons College, Graduate School of Library and Information Science, 300 The Fenway, Boston, MA 02115; and Thomas D. Gillies, Director, Linda Hall Library, 5109 Cherry Street, Kansas City, MO 64110.

\section{LIBRARIAN-SCHOLAR COOPERATION}

The American Association for the Advancement of the Humanities (AAAH) and the Association of Research Libraries (ARL) have launched a joint effort to improve communication between librarians and scholars. The two associations believe that the scholarly community must be made aware of new developments in information technology, in bibliography, in interlibrary cooperation, and in library operations that are having a significant impact upon research and teaching. At the same time, research libraries require increased support from scholars and administrators as they adjust to changing economic circumstances and expanding technologies.

The current effort is aimed at reaching scholars in two ways: through national associations and on individual university campuses. To begin the dialogue on campus, the libraries of Princeton University and the Universities of North Carolina at Chapel Hill and Colorado will participate in a one-year test distribution of a newsletter describing important developments in research libraries.

The bimonthly publication, Library Issues, will be distributed to each faculty member at the three campuses, with an appropriate follow-up by the library directors. During the year, effect of the distribution will be assessed to see whether faculty interest in the library has been stimulated. The project is supported by a grant from the Council on Library Resources, Inc.

Communication through scholarly associations will be initiated by increasing library visibility at annual meetings of scholarly societies and through the publications of the societies. Discussions of library problems and developments, demonstrations of new technologies and data bases, and articles about changes in libraries that relate to scholarly research would all considerably aid the users of research libraries. 


\section{Copyright Hotline}

The Copyright Office in Washington, D.C., has taken a step to speed up the process of obtaining copyright applications by establishing a hotline service.

In order to use the 24-hour service, you must know in advance which application forms you need to apply for copyright. The hotline records all requests which are then filed and mailed promptly, according to the Copyright Office

The telephone number of the Forms Hotline is (202) 287-9100.

If you do not know what forms you need, or if you want additional information about copyright, call the Copyright Public Information Office at (202) 287-8700 weekdays between 8:30 a.m. and 5:00 p.m. Calls are answered in sequence.

Because it is often difficult to get through to the Copyright Office by telephone, ACRL members may want to write to the office and request a listing of application form categories for future reference. If you wish to register a claim to copyright, you can refer to the listing to determine which application form is needed and request it through the hotline service. Write to the Copyright Office, $\mathrm{Li}$ brary of Congress, Washington, DC 20559.

\section{CALL FOR PAPERS: ONLINE SEARCHING}

The Machine-Assisted Reference Section of the Reference and Adult Services Division of the American Library Association will host a twopart, day-long conference devoted to an introduction to online searching for novice searchers, and an introduction to the management of an online search service. The conference will be held in conjunction with ALA's 1982 annual convention in Philadelphia.

All papers will be reviewed, and their presentation will be recorded at the conference. An outline of the topics to be addressed for each part of the conference can be ubtained by writing to:

James J. Maloney

RASD/MARS Program Committee Chair clo Bibliographical Center for Research 245 Columbine

Suite 212

Denver, CO 80206 .

Each talk should be approximately 20 minutes in length. A 250-300 word abstract should accompany an intent to submit no later than December 15, 1981. Inquiries and abstracts should be forwarded to the Program Committee Chair.

\section{If You've Got A Problem We're Just A (Free) Phone Call Away!}

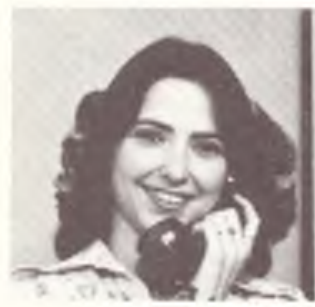

Linda Market

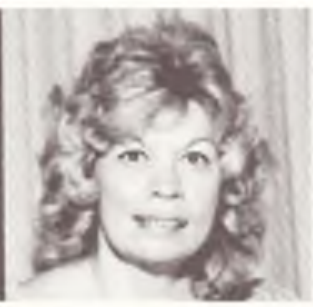

Carol Lehmkuhl

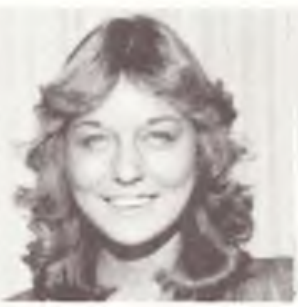

Pam Rodgers

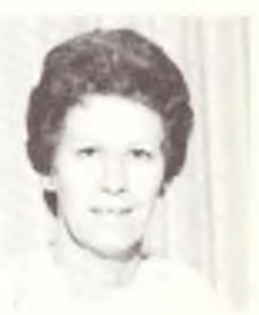

Pat Hamil

Linda and Carol, Pam and Pat are Midwest Library Service's Personal Customer Service Representatives who are specially trained to solve any book ordering problem your library may encounter. They are thoroughly knowledgeable in all facets of the library jobber business, and if you are ever in need of their services, you can reach them by using our TOLL-FREE WATS Line, 1-800-325-8833 (Missouri customers please call COLLECT: 0-314-739-3100) for help in solving any problem. Your Customer Service Representative will follow the problem through to a satisfactory conclu" 20 Years of Service To College and University Libraries" sion - without delay. Remember Linda and Carol, Pam and Pat are "working" for you and your library. It's all part of Midwest Library Service's iradition of excellence. 

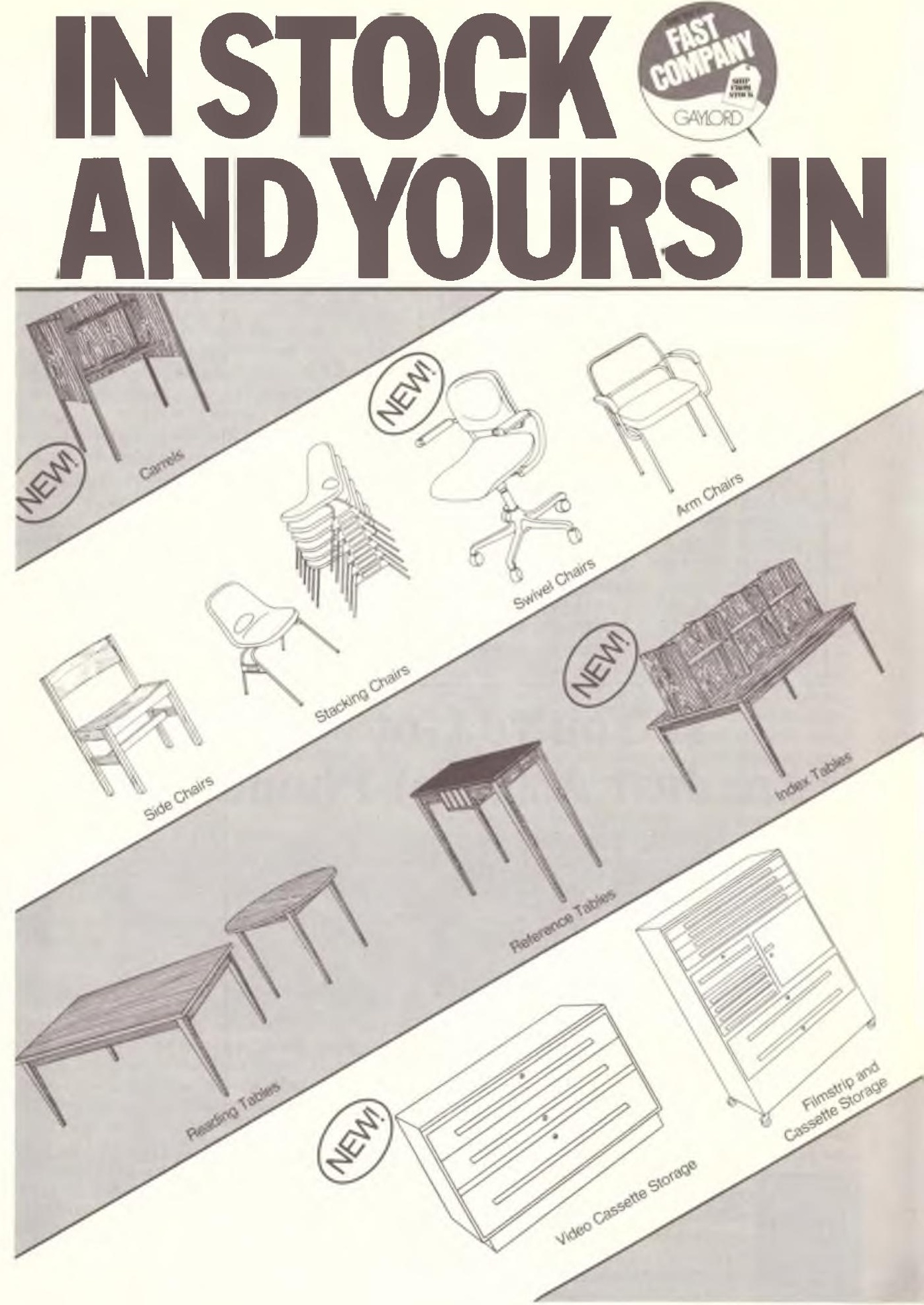


\section{WITH GAYLORD \\ "SHIP FROM STOCK" \\ YOU'RE IN FAST COMPANY.}
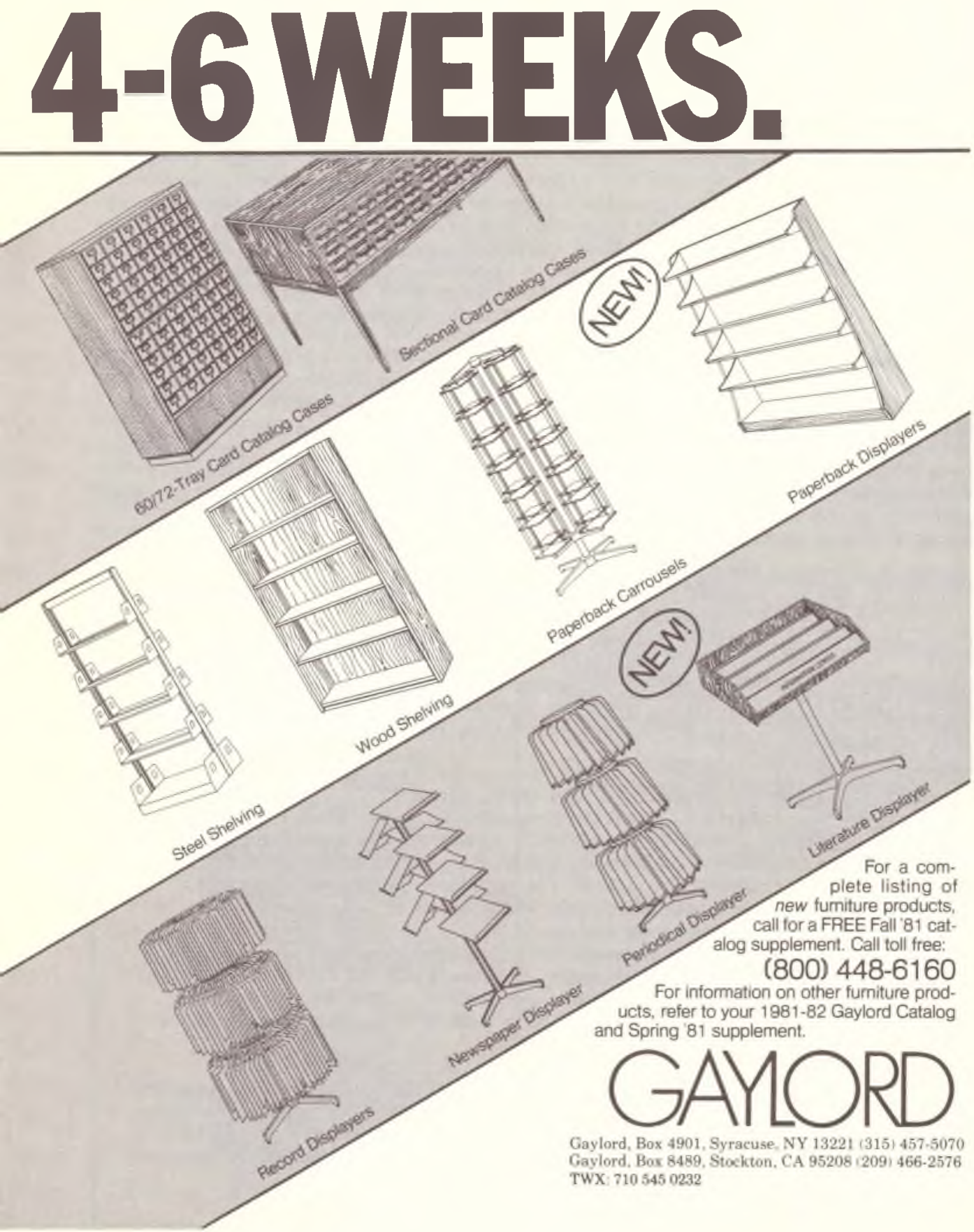